\title{
Using Outstanding Translated Children's Books in the School Setting to Promote an Understanding of Other Countries and Cultures
}

\section{MAUREEN WHITE}

\author{
University of Houston-Clear Lake, \\ Houston, Texas, USA \\ white@cl.uh.edu
}

\section{NANCY BLUEMEL}

Grapevine-Colleyville Independent School District,

Colleyville, Texas, USA

nbluemel@airmail.net

\begin{abstract}
The importance of translated children's books to the literary and cultural development of children is well documented, and the study of other countries is an important part of the school curriculum across grade levels. Therefore, purposes of the research were: (a) to share results of research on outstanding translated children's books published from 1990-2000 and provide a bibliography of these books that can be used by librarians, teachers, and students in a study of other countries; and (b) to present an application of a collaborative study on the use of translated books by a middle school librarian and teachers in a real-life setting.
\end{abstract}

\section{INTRODUCTION}

The study of other countries is an important part of the school curriculum across all grade levels. Internet access, internationally-based companies, and the ease of travel, has our students living in a global society and in the future they will be working in this global society. It is our responsibility as educators to prepare them to the best of our ability to be able to function in a world community. This article serves a two-fold purpose: (a) to share results of a study on outstanding translated children's books published from 1990-2000 and provide a bibliography of these books that can be used by librarians, teachers, and students in a study of other countries; and (b) to present an application of the use of translated books by a school librarian and teachers in a real-life setting.

It is essential that we know geographical and cultural facts about nations. As important as this information is, it is perhaps more important that students acquire a deeper understanding of other people's lives. With this in mind the teachers and the librarian at Colleyville Middle School (Texas) have included a literature strand in the research project on countries of the world that is required of the students. The rationale for this project is rooted in a quote from Aidan Chambers: 
It is through literature that we most intimately enter the hearts and minds and spirits of other people. And what we value in this is the difference as well as the human similarities of others: that way, as C.S. Lewis put it, we become a thousand different people and yet remain ourselves (Tomlinson, 1998, p. 3).

Through the use of literature individuals emerge from faceless populations and students begin to reject stereotypes. They recognize the role that history, setting, and current circumstances play in shaping all of us.

Children deserve the best literature from their home country and from abroad. Yet books from other countries, particularly translated children's books, have a difficult time making there way to the library shelves in the United States. Perhaps this difficulty comes from having such a wealth of good books written and illustrated by those in our own country, that book budgets do not expand enough to add some of the best from abroad. Reading the books from other cultures, countries and languages is commonly regarded as one important avenue of experiencing common ties, such as the need for love, family, safety, and humor that bind us together. According to Lynch-Brown and Tomlinson, translated books help children "develop a bond of shared reading experiences with children of other languages." (Lynch-Brown and Tomlinson, 1998, pp. 197-198). Yet, as author, poet, and editor Naomi Shihab Nye (1992) contends, "Those of us living in the United States often suffer from a particular literary provinciality, imagining ourselves to be the primary readers and writers of the planet." She concludes, "We need translations to help us value the literature and cultures of other languages." (pp. xii-xiii).

Outstanding translated children's books that are true to a culture, its people, and their heritage in both text and illustrations, and that are "readable," can help children value another culture at an early age. Whether culturally specific or not, outstanding translated children's books open the literature of other cultures to children, librarians, and teachers who otherwise would never be aware of its existence. The power and appeal of illustrated books for all ages from other cultures and other languages provide a diversity of viewpoints, with illustrations and styles unique and different from our own. In an interview translator, linguist, and publisher Dagmar Herrmann said "I believe from a very tender age children ought to be exposed to writers and illustrators around the world -- writers with a different view and illustrators with a different touch." ("Talking Translations," 1994, p. 40-41).

According to The Bowker Annual (1998), some 4500 to 5000 children's books are published each year in the United States. Children's literature authorities differ slightly as to the number of translations included in this large number. Yet there is agreement that there is a small number of translations, most being picture books, published in the United States each year. Horning, Kruse, and Schliesman (1994, p. 9) of the Cooperative Children's Book Center (CCBC) estimated that of the total number of children's books published in 1994, fewer than 100 were translated children's books and that the number was probably closer to 80. In 1999 Horning, Kruse, and Schliesman (2000) reported that the CCBC had received only 46 review books that were published in the United States in English after being translated from other languages, with only six of length substantial enough to make them eligible for the Batchelder Award. $C C B C$ Choices selected 8 titles for inclusion in their 2000 listing, of which 5 were picture books.

To encourage the publication of translated children's books in the United States, the Mildred L. Batchelder Award was established in 1966. This award is selected by a committee appointed by the Association of Library Services to Children of the American Library Association and awarded to the publisher of the most outstanding of children's 
books translated from another language into English and published in the United States (Mildred L. Batchelder Award, 2000). Although primary attention is given to the text for Batchelder consideration, outstanding picture books for older children have been selected as Batchelder Award Books. They include Rabbit Island (1978); Hiroshima No Pika (1982); and Rose Blanche (1986) as well as Batchelder Honor books, Vendela in Venice (1999), Star of Fear, Star of Hope (1995) and Anne Frank: Beyond the Diary (1993).

\section{Study of Translated Books by Maureen White}

Selecting quality translations for the school library collection is essential if students are to have a valid portrayal of the people and culture of the countries they are studying. Because research on countries is conducted through the language arts department as well as the social studies curriculum, books must be evaluated for both literary value and factual accuracy prior to purchase. The librarian relies heavily on reviews and studies published in professional journals in this are of collection development.

A study of the status of outstanding translated children's books published between 1990-2000 will provide data needed to analyze the factors relevant to outstanding translated children's picture books, including languages, genres, and subjects. This study should provide worthwhile information for those who study, publish, teach, and share children's literature. The author completed a study on successful translated children's books published prior to 1990 that was reported in the Journal of Youth Services in Libraries (White, 1992). A similar study on translated children's picture books published between 1992-1997 was reported in Knowledge Quest (White, 1998). Data and findings from this study, which looks at data between 1990-2000, allows the authors to draw conclusions as to trends in publishing related to language, genre, subjects, and reviews of outstanding translated books and translated picture books.

Books were selected for study that met the definition of an outstanding, translated children's book. The Association for Library Service to Children's definition of children was used: anyone from birth through fourteen years of age. An outstanding book was identified as having met one of the following criteria: (a) received an award (b) included on an identified recommended list or (c) received a favorable review in a selected children's review source. Review sources selected were Booklist, Bulletin for the Center of Children's Books, Horn Book, and School Library Journal, which according to The Bowker Annual (1996), are the primary critical review sources for school and small public libraries. A translated book was one originally written in a language other than English and subsequently translated into English and published by a United States publisher. Though there are a number of outstanding books created by authors in English-speaking nations other than the United States, the greater difficulty for U.S. librarians comes in identifying and accessing translated books. Therefore, this study was limited to translated books.

Although this study did not produce a definitive listing of translated children's books, it provides a measure of those books that received favorable reviews from selected journals. Every effort was made to identify translated children's picture books from journals, Books in Print and the Library of Congress Online Catalog.

\section{Languages}

Most reviews identify the original language of the book in the bibliographic information, but this was not always the case. Sometimes a reviewed book will not be 
indicated as a translation, yet certain authors and publishers are known for publishing translations of a specific language. Knowledge of publishers and authors come into play during this process. If there was a question the MARC record from the Library of Congress was obtained to (a) verify the original language and (b) determine whether the book is a translation or an adaptation or retelling, which were not eligible for this study.

Table 1 provides an overview of the original languages of outstanding translated children's books. Throughout the 1990's the dominant language translated by publishers in children's books was German followed by the French, Swedish, Japanese, and then by the Dutch, Italian, Danish, Spanish, and Russian languages. The close connection between English and the Germanic and Romance languages was evident in the languages being translated. Major publishers of translations with strong ties in the U.S., such as North-South for German picture book translations and Raben \& Sjogren (R\&S) for Swedish translations increased the opportunities for the publication of books from these languages. Dutch publications for the older reader are finding their way to the States primarily through the publishing efforts of Front Street. As noted in Table 1, the German and French translations continue to come, with other languages experiencing a slight decrease in terms of the number of positive reviews from the four review journals surveyed over the past 10 years.

\section{Table I}

Languages of Translated Children's Books Reviewed in Selected Journals

\begin{tabular}{|c|c|c|c|c|c|c|c|c|c|c|c|}
\hline Language & $\underline{1990}$ & $\underline{1991}$ & $\underline{1992}$ & $\underline{1993}$ & $\underline{1994}$ & $\underline{1995}$ & $\underline{1996}$ & $\underline{1997}$ & $\underline{1998}$ & $\underline{1999}$ & $\underline{2000}$ \\
\hline Afrikaans & 0 & 1 & 0 & 0 & 1 & 0 & 0 & 0 & 0 & 0 & 0 \\
\hline Chinese & 1 & 0 & 0 & 1 & 1 & 1 & 2 & 0 & 0 & 0 & 0 \\
\hline Croat & 0 & 0 & 0 & 0 & 2 & 0 & 0 & 0 & 0 & 0 & 0 \\
\hline Czech & 1 & 1 & 0 & 0 & 0 & 0 & 0 & 1 & 0 & 0 & 0 \\
\hline Danish & 5 & 1 & 5 & 1 & 3 & 1 & 0 & 3 & 2 & 0 & 1 \\
\hline Dutch & 3 & 3 & 0 & 3 & 2 & 3 & 4 & 4 & 6 & 3 & 4 \\
\hline Finnish & 2 & 1 & 0 & 0 & 1 & 0 & 0 & 1 & 0 & 0 & 0 \\
\hline French & 10 & 9 & 14 & 11 & 11 & 11 & 12 & 11 & 13 & 11 & 7 \\
\hline German & 18 & 20 & 21 & 19 & 19 & 26 & 28 & 33 & 25 & 23 & 18 \\
\hline Hebrew & 3 & 2 & 0 & 1 & 0 & 4 & 1 & 0 & 1 & 0 & 1 \\
\hline Hindu & 0 & 0 & 0 & 0 & 0 & 0 & 0 & 0 & 0 & 1 & 1 \\
\hline Hungarian & 0 & 0 & 0 & 0 & 0 & 0 & 1 & 1 & 0 & 0 & 2 \\
\hline Iroquois & 0 & 0 & 0 & 1 & 0 & 0 & 0 & 0 & 0 & 0 & 1 \\
\hline Italian & 1 & 3 & 0 & 4 & 4 & 1 & 8 & 2 & 0 & 1 & 3 \\
\hline Japanese & 6 & 4 & 9 & 6 & 4 & 3 & 1 & 1 & 2 & 4 & 40 \\
\hline Kikamba & 0 & 0 & 0 & 0 & 0 & 0 & 0 & 1 & 0 & 0 & 1 \\
\hline Korean & 0 & 0 & 0 & 1 & 0 & 0 & 0 & 0 & 0 & 1 & 2 \\
\hline Norwegian & 1 & 2 & 2 & 1 & 1 & 0 & 1 & 0 & 2 & 1 & 2 \\
\hline Polish & 0 & 0 & 2 & 0 & 0 & 0 & 0 & 0 & 0 & 0 & 2 \\
\hline Portuguese & 0 & 1 & 0 & 1 & 0 & 0 & 0 & 0 & 0 & 0 & 2 \\
\hline Russian & 3 & 1 & 3 & 3 & 2 & 2 & 3 & 0 & 1 & 1 & \\
\hline Sango & 0 & 0 & 1 & 0 & 0 & 0 & 0 & 0 & 0 & 0 & 1 \\
\hline Spanish & 1 & 4 & 3 & 0 & 3 & 4 & 4 & 2 & 1 & 3 & 0 \\
\hline Swahili & 0 & 0 & 1 & 0 & 2 & 0 & 0 & 0 & 0 & 0 & 0 \\
\hline Swedish & 9 & 8 & 7 & 5 & 4 & 3 & 6 & 3 & 1 & 3 & 5 \\
\hline Turkish & 0 & 0 & 0 & 0 & 1 & 0 & 0 & 0 & 0 & 0 & 0 \\
\hline Ukraine & 0 & 0 & 0 & 0 & 0 & 1 & 0 & 0 & 0 & 0 & 0 \\
\hline Viet & 0 & 0 & 0 & 1 & 1 & 0 & 0 & 0 & 0 & 0 & 0 \\
\hline Yiddish & 0 & 0 & 1 & 0 & 0 & 0 & 2 & 0 & 0 & 0 & 0 \\
\hline Und/Multi & 0 & 0 & 0 & 0 & 0 & 1 & 0 & 0 & 1 & 0 & 1 \\
\hline
\end{tabular}




\section{Genres}

Personal examination of the books and the information obtained from Books in Print and the Library of Congress were used to identify genres. Genre categories were consistent with genres common to those described in children's literature textbooks. Genres were consistent with those described in children's literature textbooks, including Lukens (1999). The most popular genres of translated books included the major genres of children's books being published today in the United States: Realistic Fiction, followed by Information books and Fairy tales/Folklore. During the period of the 1990s, picture books, which includes books from all other genres, accounted for the majority of translated children's books. Of these picture books, slightly more than $50 \%$ were stories of animal personification in which animals act as real people. A number of the picture books were appropriate and useful for all ages. It was decided to include stories of animal personification in Realistic Fiction when the story was realistic and not a pure fantasy. A book such as Dragon Sword and Wind Child (1993) would be considered a fantasy. See Table 2 for genres of translated children's books reviewed in selected journals.

\section{Table 2}

\section{Genres of Translated Children's Books Reviewed in Selected Journals}

\begin{tabular}{lrrrrrrrrrrrrr}
\hline Genre & 1990 & 1991 & 1992 & 1993 & 1994 & $\underline{1995}$ & 1996 & $\underline{1997}$ & $\underline{1998}$ & $\underline{1999}$ & $\underline{2000}$ \\
\hline Fairy \& & 9 & 0 & 15 & 14 & 7 & 7 & 8 & 9 & 5 & 8 & 3 \\
Folklore & 5 & 3 & 1 & 6 & 2 & 2 & 8 & 8 & 3 & 4 & 4 \\
Fantasy & 31 & 38 & 32 & 29 & 32 & 20 & 32 & 26 & 30 & 31 & 23 \\
Realistic Fiction & 31 & 4 & 0 & 1 & 3 & 7 & 3 & 5 & 2 & 1 & 2 \\
Historical & 2 & & & & & & & & & & \\
Fiction & 12 & 15 & 17 & 10 & 19 & 10 & 19 & 11 & 12 & 6 & 6 \\
Information/Bio & 2 & 0 & 6 & 3 & 0 & 1 & 3 & 1 & 3 & 2 & 0 \\
Poetry & 3 & 2 & 2 & 1 & 0 & 1 & 0 & 20 & 0 & 0 & 1 \\
Religion/Myth & 7 & 2 & 7 & 7 & 4 & 5 & 4 & 6 & 2 & 4 & 1 \\
Classics & 37 & 25 & 39 & 24 & 27 & 27 & 53 & 36 & 34 & 31 & 29 \\
Picture Books & 4 & 5 & 7 & 6 & 3 & 7 & 11 & 2 & 4 & 1 & 3 \\
Series & 4 & & & & & & & & & \\
\hline
\end{tabular}

\section{$\underline{\text { Subjects }}$}

Subjects of translated children's books closely parallel other children's books published in the United States. Popular subjects included Animals (specific)-Fiction, Fairy Tales/Folklore, Family Relationships-Fiction and Friendship-Fiction. Holocaust books or realistic fiction related to World War II were subjects not typically found in non-translated books published in the United States, but this subject was found more often in translated textual books published between 1991-1997. A notable exception was the 1996 Batchelder Honor book, Star of Fear, Star of Hope, a picture storybook. In 1998, 1999, and 2000, textual translations gave more attention to personal problems, such as death, loneliness, and child abuse, than in the past. Interestingly, in 2000 there were four books, designated as 
"Toy and movable books." While translated picture books focused more on subjects related to family, friendship and animals. For each book selected for study, subject headings were taken from the children's subject headings assigned by the Library of Congress for analysis. See Table 3 for a listing of subject headings that were assigned to more than 3 translated books.

Table 3

Subjects of Translated Children's Books Reviewed in Selected Journals

\begin{tabular}{|c|c|}
\hline$\underline{\text { Year }}$ & Major Subject Headings (more than three listings) \\
\hline 1990 & $\begin{array}{l}\text { Fairy tales/Folklore - (Specific Country) } \\
\text { Friendship - Fiction } \\
\text { Animals \& (Specific Animal) - Fiction }\end{array}$ \\
\hline 1991 & $\begin{array}{l}\text { Countries (Specific) - Fiction } \\
\text { Animals (Specific) - Fiction } \\
\text { Family Life - Fiction } \\
\text { Friendship - Fiction } \\
\text { World War, 1939-1945 }\end{array}$ \\
\hline 1992 & $\begin{array}{l}\text { Animals \& (Specific Animal) - Fiction } \\
\text { Animals - Poetry } \\
\text { Fairy tales/Folklore (Specific Country) } \\
\text { Friendship - Fiction } \\
\text { Noah's Ark }\end{array}$ \\
\hline 1993 & $\begin{array}{l}\text { Biography - (Specific Person) } \\
\text { Dogs - Fiction } \\
\text { Fairy tales/Folklore - (Specific Country) } \\
\text { Family - Fiction } \\
\text { Friendship - Fiction } \\
\text { Holocaust Survivors - Fiction } \\
\text { War - Fiction }\end{array}$ \\
\hline 1994 & $\begin{array}{l}\text { Animals \& (Specific Animals) - Fiction } \\
\text { Countries - (Specific) } \\
\text { Dinosaurs } \\
\text { Fairy tales/Folklore (Specific Country) } \\
\text { Friendship - Fiction } \\
\text { War - Fiction }\end{array}$ \\
\hline 1995 & $\begin{array}{l}\text { Animals \& (Specific Animals) - Fiction } \\
\text { Art \& Art appreciation-Fiction } \\
\text { Biography - (Specific Person) } \\
\text { Fairy tales/Folklore (Specific Country) } \\
\text { Family life - Fiction } \\
\text { Friendship - Fiction } \\
\text { Holocaust survivors - Fiction } \\
\text { Human Behaviors - Fiction } \\
\text { World War II - Fiction }\end{array}$ \\
\hline
\end{tabular}

Inspiring connections: Learning, libraries \& literacy 
1996

1997

1998

1999

2000
Animals \& (Specific Animals) - Fiction

Humorous stories

Artists (Specific Names), Painters

Fairy tales/Folklore (Specific Country)

Holocaust, Jewish

Animals \& (Specific Animal) - Fiction

Fairy tales/Folklore (Specific Country)

Friendship - Fiction

Jews/Holocaust

Personal attributes (e.g., Self-acceptance, Bashfulness,

Cooperativeness)

Witches - Fiction

Animals \& (Specific Animals) - Fiction

Family relationships - Fiction (e.g., Sisters - Fiction)

Fairy tales/Folklore (Specific Country)

Poetry

Emotional problems - Fiction (e.g., Death, Loneliness, Prejudices)

Feelings (e.g., love, courage) - Fiction

Geographic locations - Fiction

Animals \& (Specific Animals) - Fiction

Fairy tales/Folklore (Specific Country)

Personal problems - Fiction (e.g., Death, Child Abuse, Emotional problems)

Geographic places (Specific) - Fiction

Artists - Fiction

Family relationships - Fiction (e.g., Sisters - Fiction)

Friendship - Fiction

Animals \& (Specific Animals) - Fiction

Family relationships - Fiction (e.g., Mothers and daughters, Grandparents)

Geographic places (Specific) - Fiction

Art history and Art appreciation

Holocaust/Jews - Fiction

Personal problems - Fiction (e.g., Fear, Grief, Anger, Stealing)

Toys and movable books

Fairy tales/Folklore

\section{$\underline{\text { Reviews }}$}

Reviews of translated children's books by major review sources ensure that the books are noticed by children's librarians. The average number of reviews for the past 10 years (1990-2000) was 82.8 per year. The largest number of reviews appeared in 1998 with 99 reviews from the selected sources. The smallest number of reviews appeared in 1994 with only 56 reviews cited. Providing the most reviews was School Library Journal, followed by Booklist. Horn Book and Bulletin for the Center of Children's Books selected a smaller 
number of translations for review each year, but they also review a much smaller number of books than does Booklist or School Library Journal. See Table 4 for a number of reviews by year from review sources used in this study.

\section{Table 4}

Translated Children's Books Reviewed in Selected Journals

\begin{tabular}{lrccccc}
\hline$\underline{\text { Year }}$ & BCCB & Booklist & Horn Book & $\underline{\text { SLJ }}$ & Total \\
\hline 1990 & 11 & 4 & 8 & 48 & 91 \\
1991 & 12 & 24 & 9 & 34 & 79 \\
1992 & 3 & 23 & 3 & 44 & 73 \\
1993 & 10 & 23 & 9 & 34 & 76 \\
1994 & 9 & 28 & 4 & 15 & 56 \\
1995 & 14 & 30 & 7 & 34 & 85 \\
1996 & 13 & 22 & 5 & 54 & 94 \\
1997 & 9 & 32 & 6 & 40 & 87 \\
1998 & 9 & 42 & 7 & 41 & 99 \\
1999 & 7 & 20 & 9 & 47 & 83 \\
2000 & 5 & 24 & 6 & 38 & 73 \\
\hline
\end{tabular}

\section{Trends}

The majority of outstanding translated children's books, including picture books, are from the German and the French languages, reflecting the close ties of language, culture and literature between these nations and the United States. The North-South publishing house continues to send us a large number of picture book translations from the German language. The large number of Swedish titles is a result of the cooperative ventures between the publisher Farrar, Straus, and Giroux and the Swedish firm, Raben \& Sjogren (R\&S). Books from the French language come from a variety of publishers and include a number of information books on the subject of art and artists as well as picture books for the younger reader. Front Street has given us a small collection of outstanding translations from the Dutch language. A new publishing house, Barefoot Books, has been instrumental in publishing several Italian translations. Connections between foreign publishers and publishers in the United States seems to be the primary impetus for continued translations of a particular language.

Genres of realistic fiction (including stories of animal personification), information books, folklore, and fantasy and are frequently translated genres of children's translated books. These genres are also popular in non-translated children's books in the United States. Information books seem to be on the increase for all books, including picture books. Awards for information books, including the Orbis Pictus Award, increasing number of articles and books addressing the value and popularity of nonfiction literature, and exceptional authors who write in this field, have brought attention and increased publication of this literature. 
Subjects with universal appeal are the subjects of translated children's picture books. Animal stories, information books and fairy tales/folklore are major subjects of the books selected for study. Information books on art appreciation and famous artists were most common for this genre. Books based on personal problems (e.g., death, emotional problems) are on the increase, although these books may be more difficult to sell in the U.S. market as we have more of a tendency to avoid serious subjects in younger children's literature than does the literature from abroad.

Reviews of translated children books and particularly picture books continue to come from major review journals. Although the four review journals selected for use in this study are still the major journals used for selection by librarians, additional critical review sources have become available online. Online sources, such as Amazon.com, BarnesandNobles.com and Borders.com, places into the hands of children's librarians not only the four review sources used in this study, but also additional review sources less likely to be subscribed to by school and small public libraries. These include such critical review sources as Kirkus Reviews, Publisher's Weekly, Library Journal and The New York Times Book Review. In a future study of translated children's books, these resources will also be included to increase the possibility of inclusion into the database of books to be studied.

In spite of the fact that publishers continue to produce a relatively small number of translated children's books, there is available a wide selection of outstanding translations. There is a particularly outstanding selection of picture books from all genres, subjects and from a variety of languages being published. Many translated books have received positive reviews and a few were placed on notable lists and/or received children's book awards. It is our responsibility as children's librarians teachers, and/or parents to access these books of quality and share with children. If we begin this venture of sharing outstanding translated children's picture books with children at an early age, we validate to children that outstanding literature does not just come only from our own country, but comes from many other countries and languages around the world.

\section{Application by Nancy Bluemel}

Planning of the research project on countries is a collaborative effort between teachers and the librarian. It was organized in the following manner:

1. Prior to beginning research in the library, each student meets with the teacher in the classroom to select the country he/she would like to know more about. Travel packets which detail specific information the students must discover while working in the library are distributed.

2. Students come to the library media center as a class every day for 3-5 days for time periods that range from 45 minutes to $1 \frac{1}{2}$ hours. After this time, they will be expected to gather any additional information they may need before or after school until the date the final project is due to be submitted to the teacher. On the first day in the library two things are accomplished.

a. The librarian teaches students which print and electronic resources will be most beneficial to their fact-finding mission.

b. The librarian assists each student in selecting a piece of authentic literature to read at home while they are conducting their research in the school library. 
3. On the second day, prior to beginning their research, the librarian discusses with the students three things to be aware of as they read the book they have selected. They are given these instructions.

a. Watch for details woven into the storyline, such as references to food, weather, leisure activities, family celebrations, etc., which can help you to have a clearer picture of life in the country in which your book is set.

b. If the book is historical fiction or of a biographical nature, are you familiar with the events or famous people described in the story? If not, learn something about them so the story will be more meaningful to you.

c. What, if any, impact do current, historical geographical, or cultural circumstances have on the actions of the characters? This will require some critical thinking on your part and may possibly require a search for additional information.

4. Throughout the research process, the students continue to compare the facts they are finding with "leads" in the literature which will help them to a better understanding of the country they have chosen to study and the people who live there.

5. Two assignments are to be completed at the end of this project.

a. Students must submit a pictorial diary, which is based on the facts they have discovered in the research portion of their study.

b. Students conduct "book chats" in which they tell their classmates briefly about the setting and plot of the work of authentic literature they read. They explain how this book helped expand their knowledge and understanding of the people of the country in a way that the facts they gathered could not. They are reminded in preparing for the "book chat" to consider references to cultural, historical, and geographical circumstances in the story and how those affected the lives and actions of the people.

6. An international book display is held in the library to promote the reading of authentic literature. Everyone is encouraged to put their "book chat' information into a written format titled, "May I recommend a trip to . . .?" (See Appendix A.) It is placed next to the book to inspire others to check it out.

\section{Outreach}

Colleyville Middle School has a Library Club, which is an extracurricular orgaization comprised of students interested in literature, promoting school library programs, and community service. The group's advisors are the school librarian and a language arts teacher.

An annual event for the club is the presentation of an evening of reader's theater for elementary school age children is held at a local bookstore. Using retellings and translations of folk and fairy tales from around the world, club members write their own scripts. With simple props to aid the young audience in character identification, they read their "classic" tales. In many instances, they invite audience participation. 
This program which is held every spring and advertised by the bookstore has become very popular with local children and their parents. Reaching out and sharing translated literature within the community opens another avenue with which to expose both young and old to the literary cultural roots of the nations of the world.

\section{CONCLUSIONS}

Combining the reading of authentic literature with research has proven to be an excellent way to give students an emotional and not just factual insight into other countries. It has also provided a benefit that the teachers and librarian were not expecting. Many students said they never would have checked out the books that they were required to read. They began reading them reluctantly; finished them enthusiastically saying, "That was a really good book." We have inadvertently created an audience for international literature in our schools. (See Appendix B for books applicable for this type study.)

\section{REFERENCES}

The Bowker annual: Library and book trade almanac 1998. (1998). (43 ${ }^{\text {rd }}$ ed., p. 543). New Providence, NJ: Bowker.

The Bowker annual: Library and book trade almanac 1996. (1996) $\left(41^{\text {st }}\right.$ ed., pp. 543-546). Providence, NJ: Bowker.

Horning, K. T., Kruse, G. M., \& Schliesman, M. (2000). CCBC choices 2000, (p. 15). Madison WI.

Horning, K. T., Kruse, G. M., \& Schliesman, M. (1994). CCBC choices 1994, (p. 9). Madison WI.

Lynch-Brown, C., \& Tomlinson, C. (1998). Essentials of children's literature ( $3^{\text {rd }}$ ed.). Boston: Allyn and Bacon.

Nye, N. S. (1992). This same sky: A collection of poems from around the world. New York: Four Winds Press.

Talking translations: An interview with Dagmar Hermann. (1994). Booklinks, 3, 40-41.

Tomlinson, C. M. (1998). Children's books from other countries. Lanham MD: Scarecrow Press.

Web site: Mildred L. Batchelder Award, Association for Library Service to Children. Available: http://www.ala.org/alsc/batch.html.

White, M. (1998). Best children's picture books from abroad: Valuing other cultures. Knowledge Quest, 27, 17-23.

White, M. (1992). Children's books from other languages: A study of successful translations. Journal of Youth Service in Libraries, 5, 261-275. 


\section{APPENDIX A}

May I recommend a trip to ...?

Author:

Title:

Setting:

Time Period:

Synopsis of Plot:

This book helped me expand my knowledge and understanding of the country in which this story took place and of the people who live there in the following ways:

Student's name: 


\section{APPENDIX B}

\section{Recommended List of Translated Children's Books}

\section{Useful for Cultural/Country Studies}

Each selected book has received at least two favorable reviews, was named as a Children's Notable Book or received an award. The bibliography is organized by year with countries or cultures indicated in parentheses. In addition to works of realistic fiction and historical fiction, outstanding translations of poetry, information, and folktales are included that may be useful to for the application presented in this study.

$\underline{2000}$

Carmi, D. (2000). Samir and Yonatan. Translated from the Hebrew by Yael Lotan. New York: Arthur Levine/Scholastic. (Ages 9-12). Israel and Palestine.

Enzenberger, H.M. (2000). Lost in time. Translated from German by Anthea Bell. New York: Holt. (Ages 12-14) Germany.

Moeyaert, B.(2000). Hornet's nest. Translated from the Dutch by David Colmer. Asheville, NC: Front Street. (Ages 12 \& up) Holland.

Pressler, M. (2000). Anne Frank: A hidden life. Translated from the German by Anthea Bell. New York: Dutton. (Ages 12 \& up) Germany/Holland.

Visconti, G. (2000). The genius of Leonardo. Translated by Mark Roberts. New York: Barefoot Press. (Ages 8-12) Italy.

Vos, I. (1999). The key is lost. Translated by Terese Edelstein. New York: Harpercollins. (Ages 10-14). Holland.

\section{9}

Ada, A. F. (1999). Under the royal palms: A childhood in Cuba. Illustrated by Nina Barnett. New York: Atheneum. (Ages 9-14) Cuba.

Björk, C. (1999). Vendela in Venice. Illustrated by Inga-Karin Eriksson. Translated from the Swedish by Patricia Crampton. New York: R\&S, 1999. Batchelder Honor Award, 2000(Ages 10 \& up) Italy.

Guarnieri, P. (1999). A boy named Giotto. Illustrated by Bimba Landmann. Translated from the Italian by Jonathan Galassi. New York: Farrar. (Ages $5 \&$ up) Italy.

Holtwijk, I. (1999). Asphalt angels. Translated from the Dutch by Wanda Boeke. Asheville, NC: Front Street. Batchelder Honor 2000. (Ages 13 \& up) Rio de Janeiro, Brazil.

Montejo, V. Popol Vuh: A sacred book of the Maya. Translated from Spanish by David Unger. Toronto: Groundwood. (Ages $11 \&$ up). Mayan/Central America/Mexico.

Quintana, A. (1999). The baboon king. Translated from the Dutch by John Nieuwenhuizen. New York: Walker. Batchelder Award 2000. (Ages 12 \& older). Africa/Masai \& Kikuyu Tribes.

Yumoto, K. (1999). The spring tone. Translated from the Japanese by Cathy Hirano. Farrar. (Ages 11-14) Japan. 
Enzensberger, H. M. (1998). The number devil: A mathematical adventure. Illustrated by Rotraut Susanne Berner. Translated from German by Michael Henry Heim. New York: Holt. (Ages 10 \& 14) Germany.

Gollub, M. (1998). Cool Melons Turn to Frogs: The Life and Poems of Issa. Illustrated by Kazuko Stone. Translated from the Japanese by Matthew Gollub. New York: Lee \& Low, 1998. (Ages 8-11) Japan.

Kharms, D. (1998). It happened like this: Stories and poems. Translated from the Russian by Ian Frzier. Illustrated by Katya Arnold. New York: Farrar. (Ages 10 \& up) Russian.

Morgenstern, S. (1998). Secret letters from 0-10. Translated from the French by Gill Rosner. New York: Viking. (Ages 9-12) France.

Nye, N. S. (1998). The space between our footsteps: Poems and paintings from the Middle East. New York: Simon \& Schuster. (Ages 12 \& up). Middle Eastern countries.

Rabinovici, S. (1998). Thanks to my mother. New York: Dial Books. Batchelder Award 1999. (Ages 13 \& up). Lithuania/Germany.

$\underline{1997}$

Andersen, H. C. (1997). The Emperor's New Clothes. Illustrated by Angela Barrett. Translated from the Danish by Naomi Lewis. Cambridge, MA: Candlewick, 1997. CCBC Choices 1997. (Ages 6-9) Denmark.

Heindenreich, E. (1997). Nero Corleone: A cat's story. Illustrated by Quint Buchholz. Translated from the German by Doris Orgel. New York: Viking. 1998 Batchelder Honor. (Ages 8-11) Italy.

Holub, J. (1997). The robber and me. Translated from the German by Elizabeth Crawford, New York: Holt. 1998 Batchelder Award. (Ages 10-13) Germany.

Novac, A. (1997). The beautiful days of my youth: My six months in Auschwitz and Plaszow. Illustrated with photographs. Translated from the French by George Newman. New York: Holt. (Ages 12 \& up) Poland \& Germany.

Spivak, D. (1997). Grass sandals: The travels of Basho. Illustrated by Demi. New York: Atheneum. (Ages 7-11) Japan.

Wassiljewa, T. (1997). Hostage to war: A true story. Translated from the German translation of the original Russian by Anna Trenter. New York: Scholastic. Batchelder Honor 1998. (Ages 12 \& up) Germany and Russia.

\section{$\underline{1996}$}

Kharms, D. (1996). First, second. Illustrated by Marc Rosenthal. Translated from the Russian by Richard Pevear. New York: Farrar. (Ages 6-11) Russia.

Maples in the Mist: Children's Poems from the Tang Dynasty. Illustrated by Jean and Mousien Tseng. Translated from the Chinese by Minfong Ho. New York: Lothrop. (Ages 7-12) China.

Out of the Dumps: Writing and Photographs by Children from Guatemala. Edited by Kristine L. Franklin and Nancy McGirr. Translated from the Spanish by Kristine L. Franklin. New York: Lothrop. (Ages 10-14) Guatemala.

Popov, N. (1996). Why? Illustrated by author. Title translated from the German. New York: North-South. (Ages 10 \& up). Germany. 
Pausewang, G. (1996). The final journey. Translated from the German by Patricia Crampton. New York Viking. (Ages 13 \& up). Germany.

Yumoto, K. (1996). The friends. Translated from the Japanese by Cathy Hirano. New York: Farrar. Batchelder Award 1996. (Ages 10-14) Japan.

$\underline{1995}$

Beeson, J. (1995). \{October 45: Childhood Memories of the War\}. Translated from the French by Carol Volk. Designed by Rita Marshall. San Diego: Harcourt. (Ages 9-12) France. DeVries, A. (1995). Bruises. Translated from the Dutch by Stacey Knecht. Front Street. (Ages 12 \& up). Holland.

Hoestlandt, J. (1995). Star of Fear, Star of Hope. Illustrated by Johanna Kang. Translated from the French by Mark Polizzotti. New York: Walker. (Ages 8 \& up) France.

Jicai, F. (1995). Let one hundred flowers bloom. Translated from the Chinese by Christopher Smith. New York: Viking. (Ages 11 and up) China.

Kodama, T. (1995). Shin's Tricycle. Illustrated by Noriyuki Ando. Translated from the Japanese by Kazuko Hokumen-Jones. New York: Walker. (Ages 9-14) Japan.

Lee, J. M. (1995). The Song of Mu Lan. Illustrated by Jeanne M. Lee. Translated from the Chinese. Arden, NC: Front Street. (Ages 4-10) China.

Morgenstern, C. (1995). Christian Morgenstern: Lullabies, Lyrics and Gallows Songs. Selected and illustrated by Lisbeth Zwerger. Translated by Anthea Bell. New York: NorthSouth. (Ages 5-9) Germany.

Orlev, U. (1995). The lady with the hat. Translated from the Hebrew by Hillel Halkin. Boston: Houghton Mifflin. Batchelder Award 1996. (Ages 12 \& up). Israel.

Pausewang, G. (1995). Fall-out. Translated from the German by Patricia Crampton. New York: Viking (Ages 12-15) Germany.

The tree is older than you are: A bilingual gathering of poems and stories from Mexico, with paintings by Mexican artists. Selected by Naomi Shihab Nye. New York: Simon \& Schuster. (All ages) Mexico.

Vos, I. (1995). Dancing on the Edge of Avignon. Translated from the Dutch by Terese Edlstein and Inez Smidt. Boston: Houghton Mifflin.

\section{4}

Dalokay, V. (1994). Sister Shako and Kolo the goat: Memories of my childhood. Translated by Guner Ener. New York: Lothrop. Batchelder Honor 1995. (Ages 10 \& up) Turkey.

Filipovic, Z. (1994). Zlata's diary: A child's life in Sarajevo. Translated with notes by Christina Pribichevich-Zorc. New York: Viking. (Ages 9-15) Bosnia \& Herzegovina.

Friedman, C. (1994) Nightfather. Translated from the Dutch. Cambridge MA: Persea. (Ages 10 \& up) Netherlands.

I Dream of Peace: Images of War by Children of Former Yugoslavia. Preface by Maurice Sendak. Translated by UNICEF translators. New York: HarperCollins, 1994. (Ages 10+) Poetry.

Picó, F. (1994). The Red Comb. Illustrated by María Antonia Ordóñez. Translated from the Spanish by Argentina Palacios. Mahwah NJ: BridgeWater. (Ages 7-10) Puerto Rico.

Reuter, B. The boys from St. Petri. Translated by Anthea Bell. New York: Dutton. Batchelder Award 1995. (Ages 11 \& up) Denmark. 
Kharms, D. (1993). The Story of a Boy Named Will, Who Went Sledding Down the Hill. Illustrated by Vladimir Radunsky. Translated from the Russian by Jamey Gambrell. New York: North-South. (Ages 4-9) Russia.

Llorente, P. M. (1993). The apprentice. Translated from the Spanish by Robin Longshaw. Illustrated by Juan Ramon Alonso. New York: Farrar. Batchelder Award 1994. (Ages 10-14) Italy.

Ogiwara, N. (1993). Dragon sword and wind child. Translated from the Japanese by Cathy Hirano. New York: Farrar. (Ages 12 \& up).Japan.

Orlev, U. (1993). Lydia, queen of Palestine. Translated from the Hebrew by Hillel Halkin. Boston: Houghton Mifflin. (Ages 10 \& up). Romania \& Israel.

Verhoeven, R., \& van der Rol, R. (1993). Anne Frank: Beyond the Diary. Translated from the Dutch by Tony Langhamn and Plym Peters. New York: Viking, 1993. 1994 Batchelder Honor Book. (Ages 11+) Holland \& Germany.

Vólavkova, H. (ed.) (1993). I never saw another butterfly . . .. Children's drawings and poems from Theresienstadt Concentration Camp, 1942-1944. Translated by Jeanne Nemkova. (Ages 10 \& up) Czechoslovakia.

\section{$\underline{1992}$}

Bernos de Gasztold, C. (1992). Prayers from the Ark. Illustrated by Barry Moser. Translated from the French by Rumer Godden. New York: Viking. (All ages).

Cassedy, S. (1992). Red Dragonfly on my Shoulder. Illustrated by Molly Bang. Translated from the Japanese by Sylvia Cassedy and Kunihiro Suetake. New York: HarperCollins. (All ages) Japan.

Demi. (1992). In the Eyes of the Cat. Translated from the Japanese by Huang.. New York: Holt. (Ages 4-8) Japan.

Mado, M. The Animals. Illustrated by Mitsumasa Anno. Translated by The Empress Michiko of Japan. New York: McElderry Books. 1994 Hans Christian Andersen Author \& Illustrator Awards. (Ages 5+) Japan.

Nye, N. S. (ed.). (1992). This same sky: A collection of poems from around the world. Translated from a variety of languages. New York: Four Winds.

$\underline{1991}$

Ada, A. F. The Gold Coin. Illustrated by Neil Waldman. Translated from the Spanish by Bernice Randall. New York: Macmillan. (Ages 7-10) Mexico \& Central America.

Bjork, C. Elliot's Extraordinary Cookbook. Illustrated by Lena Anderson. Translated from the Swedish. New York: Farrar. (Ages 5-9) Sweden.

Chekkov, A. Kashtanka. Illustrated by Barry Moser. Translated from the Russian by Richard Pevear. New York: Putnam. (Ages 7-10) Russia.

Higo, T. (1991). The girl with the white flag: An inspiring story of love and courage in war time. Translated from the Japanese by Dorothy Britton. New York: Kodansha. (Ages 10 \& up) Japan.

Orlev, U. (1991). The man from the other side. Translated from the Hebrew by Hillel Halkin. Boston: Houghton Mifflin. Batchelder Award 1992. (Ages 11 \& up) Poland.

Zhensun, Z., \& Low, A. (1991). A young painter: The life and paintings of Wang-Yang China's extraordinary young artist. Translated from the Chinese by Huang Long, et al. Photographs by Zheng Zhensun. New York: Scholastic. (Ages 10-14) China. 


\section{0 and Previous Years}

Innocenti, R. (1985). Rose Blanche. Translated from the German by Elizabeth Crawford. New York: Holt. Batchelder Award 1998. (Ages 10 \& up) Germany.

Maartens, M. (1989). Paper bird. Translated by Madeleine van Biljon. New York: Clarion. (Ages 10-14) South Africa.

Marshak, S. (1990). Hail to mail. Illustrated by Vladimir Radnusky. Translated from the Russian by Richard Pevear. New York: Holt. (Ages 4-9) Russia.

Steiner, J. (1978). Rabbit island. Translated from the German by Ann Conrad Lammers. Illustrated by Jörg Muller. San Diego: Harcourt. Batchelder Award 1979. (Ages 10-14) Germany.

Tsuchiya, Y. (1988). Faithful elephants: A true story of animals, people, and war. Translated from the Japanese by Tomoko T. Dykes. Illustrated by Ted Lewin. Boston: Houghton Mifflin. (Ages $10 \&$ up). Japan. 